\title{
Energy Poverty Revisited
}

\begin{abstract}
This chapter introduces the political and scientific context in which the book is situated. It defines the terms 'energy poverty' and 'infrastructural divide' while discussing the purpose and structure of the book. The book's central aim is the consolidation and development of debates on European and global energy poverty, by exploring the political and infrastructural drivers and implications of the condition across a variety of spatial scales.
\end{abstract}

Keywords Energy poverty • Energy vulnerability • Fuel poverty Infrastructure • European Union energy policy

\section{INTRODUCTION}

Energy poverty occurs when a household is unable to secure a level and quality of domestic energy services-space cooling and heating, cooking, appliances, information technology - sufficient for its social and material needs. This somewhat contested and broad definition lies at the tip of a vast scientific and policy iceberg, involving complex socio-technical relations that extend across the planet. Energy poverty affects millions of people worldwide, even if the causes and consequences vary depending on context. Historically, the existence of this condition in the Global North has 
been attributed to contingencies such as low incomes, energy-inefficient homes and high energy prices, while in the Global South, the infrastructural lack of access to more technologically advanced energy carriers has been seen as the main culprit (Bouzarovski \& Petrova, 2015). It is estimated that more than one billion people across the world suffer from this condition; and it has received significant prominence thanks to high-profile international drives such as the 'Sustainable Energy for All' initiative, aimed at 'reducing the carbon intensity of energy while making it available to everyone on the planet' so as to contribute to a 'cleaner, just and prosperous world for all' (Sustainable Energy for All, 2017).

The existence of energy poverty in the 'developed' countries of the Global North was traditionally interpreted within a relatively narrow thematic and geographic register: for a long time, public recognition of the problem was limited to the UK and the Republic of Ireland. The last decade has seen as expansion of scientific and policy debates to a much wider range of countries and regions, particularly in Europe but also in North America, Japan, South Korea, Australia and New Zealand (Hilbert \& Werner, 2016; Kim, Lee, Ahn, Lim, \& Kim, 2016; Liu, Judd, \& Santamouris, 2017; Maxim, Mihai, Apostoaie, \& Maxim, 2017; Oppenheim, 2016; Scarpellini, Sanz Hernández, Llera-Sastresa, Aranda, \& López Rodríguez, 2017; Teller-Elsberg, Sovacool, Smith, \& Laine, 2016; Tirado \& Jiménez Meneses, 2016; Williams, Wooliscroft, \& Lawson, 2015). Of note is the recent establishment of a European Energy Poverty Observatory-a new initiative supported by the European Union (EU), aimed at providing a public hub for the gathering and dissemination of information on the extent and nature of domestic energy deprivation in Europe. The Observatory collects and publishes Europe-wide energy poverty data, while serving as the focal point of an emergent network of policymakers, research scientists, advocacy groups and community activists interested in the issue. It aims to improve the state of the art on energy poverty detection, measurement and reporting by creating a public forum for the exchange of knowledge on the issue (Energy Vulnerability and Urban Transitions, 2017a).

There is an expectation that the Observatory will become a decisionsupport tool for the significant amount of new EU-wide energy policy and legislation that will be developed in the near future. This process is part of a wider regulatory drive, reflected in the recent inclusion of energy poverty as a distinct thematic area in the Energy Union and Clean Energy Package proposals and the presence of the term in various EU policy documents 
since 2009. The public recognition of energy poverty has been supported, in part, by concerted advocacy efforts on the part of non-governmental organizations (NGOs), lobby groups and businesses. Recent examples include the formation of a coalition of unions, anti-poverty organizations and environmental NGOs 'committed to join efforts to fight energy poverty and defend the right to renewable energy for all', in part through 'the recognition of affordable energy as a basic human right in EU legislation' (European Anti-Poverty Network, 2017). Also of significance is the European Energy Poverty Task Force, which combines the efforts of a multinational company, think tank and charitable foundation so as to 'improve people's day-to-day lives, while offering concrete solutions to tackle climate change' (Schneider Electric, 2017).

The rising prominence of energy poverty within European policy and science agendas is likely to catalyse a new tide of discussion and deliberation. Ongoing processes of low-carbon transition have significant social justice implications, many of which intersect with key energy poverty concerns. A number of open questions have yet to be resolved, however. It remains unclear how energy poverty relates to wider dynamics of economic and political restructuring. Also, there is uncertainty over the manner in which energy poverty both affects and is reflected in household consumption practices, as well as existing vulnerabilities and forms of deprivation. There is a need to understand how spatial patterns of energy poverty map onto existing inequalities within and among cities, regions and countries, in light of the known economic and infrastructural embeddedness of the condition. Last but not the least, the link between energy poverty and processes of systemic change in the energy sector is poorly theorized in the social science literature-especially when it comes to the manner in which processes of socio-technical change create spatially embedded forms of inequality.

\section{Purpose of THE BoOK}

This book aims to both consolidate and advance debates on European and global energy poverty, by exploring the political and infrastructural drivers and implications of the condition across a variety of spatial scales. It stems from a five-year research programme centring on the European Research Council-funded Energy Vulnerability and Urban Transitions in Europe research project (Energy Vulnerability and Urban Transitions, 2017b), which aims to generate a conceptual shift in the mainstream theorization 
of domestic energy deprivation-away from the conventional focus on poverty, access and energy efficiency, onto more complex and nuanced issues of resilience and precariousness. The book thus highlights the need for a geographical conceptualization of the different ways in which household-level energy deprivation both influences and is contingent upon disparities occurring at a wider range of spatial scales. There is a strong focus on the relationships among energy transformation, institutional change and place-based factors in determining the nature and location of energy-related poverty and vulnerability.

Within its overarching purpose, the book explores how patterns and structures of energy poverty have changed over time, as evidenced by some of the common measures used to describe the condition. In part, this means exploring the makeup of energy-poor demographics across various social and spatial cleavages. I thus touch upon the regional differences that characterize domestic energy deprivation. More broadly, the book argues that energy sector reconfigurations are both reflected in, and shaped by, various domains of social and political organization, especially in terms of creating poverty-relevant outcomes.

Underpinning all of these aims is a wider argument that the inequalities generated by processes of energy system restructuring have a strong geographical component, as they involve spatial and material formations in addition to income deprivation. I contend that the multidimensional nature of energy poverty makes it difficult to capture the phenomenon via a single indicator, thus suggesting that existing measures can only depict individual facets and experiences associated with the predicament. Following Bouzarovski et al. (2017), I argue in favour of unravelling the wider political and spatial implications of energy poverty in contexts where this condition encompasses a wide range of demographic and spatial strata. This starts from the premise that, despite the recognition that indoor environments represent fluid and open spaces that are connected to broader social and ecological systems (Biehler \& Simon, 2010), mainstream work on the dynamics of domestic energy deprivation has largely focused on a relatively narrow range of explanatory factors within the home-particularly micro-economic affordability, as well as the thermal efficiency of the dwelling, heating system or appliances (Boardman, 2010). There is a need, therefore, for establishing how energy poverty is embedded in the broader system of infrastructural provision (Coutard, 2002; Marvin, 2012) and institutional change (Harrison \& Popke, 2011) while simultaneously affecting both the consumption structure and state policies that characterize energy flows. 
The book moves towards a conceptualization of domestic energy deprivation as a systemic issue that cuts across wider material and policy configurations involved in the provision of housing, the regulation of the energy sector and day-to-day political decisions. The chapters that follow, therefore, explore the embeddedness of energy poverty in socio-spatial path dependencies and reform approaches and its influence on the structure of energy demand as a result of household practices. I am also interested in the relationship between domestic energy deprivation, on the one hand, and the conduct of political debates and government decisions, on the other. More broadly, I hint at the infrastructural and political challenges that underpin the emergence of a common European energy policy. Here, my theoretical approach is predicated upon the emergent field of 'energy geographies' (Calvert, 2015; Pasqualetti \& Brown, 2014), which highlights the importance of contingencies such as place, territory, path dependency and uneven development in shaping resource flows and consumption practices alike (Bridge, Bouzarovski, Bradshaw, \& Eyre, 2013). Research in this burgeoning domain has provided multilayered accounts of global patterns of energy extraction and demand, as well as the spatial implications of socio-technical transitions towards a low-carbon and sustainable future (ibid.). I also utilize ideas from 'assemblage thinking' (Anderson \& McFarlane, 2011; DeLanda, 2006) to argue in favour of conceptualizing energy vulnerability in the EU as a heterogeneous mix of material, technical and institutional components with specific territorial ramifications.

Throughout the book, I highlight the importance of demand-side energy services in shaping both the experience and understanding of energy poverty. As part of this, I focus on the broader injustices throughout the energy chain, so as to move beyond one-dimensional analyses solely dedicated to markets or 'the state' as relevant actors (Bouzarovski, Bradshaw, \& Wochnik, 2015). The book thus pays central attention to the EU's policy role in regulating energy as a complex multisectoral issue, thus sustaining the functions that it provides for final consumers (ibid.).

\section{STructure of THe BoOK}

The remainder of the book consists of four chapters. In Chap. 2, I explore the multiple definitional issues surrounding energy poverty, vulnerability, transitions and justice, while laying out the conceptual framework that has informed my approach towards this book and the research leading up to 
it. Chapter 3 of the book explores the wider political context in which energy poverty is being addressed, scrutinizing the evolution and functioning of relevant policy landscapes at the EU level. In order to unpack the European 'infrastructural divide' - understood as an amalgamation of social and technical relations that is expressed as a set of geographical differences across a variety of scales-Chap. 4 explores how a combination of social, economic and spatial factors has created a landscape of energy vulnerability in Europe. The chapter also includes a review of energy poverty in various national, regional and urban contexts, focusing on a set of Central and East European countries where energy poverty is widespread. The wider implications of household coping practices and practices of fuel switching are also mentioned in this context. The concluding chapter returns to the aims of the book by emphasizing how the rise and persistence of energy poverty are embedded in wider political and spatial relations, as well as the manner in which various policy decisions are helping dismantle inherited and existing socio-technical divisions in Europe and beyond.

\section{REFERENCES}

Anderson, B., \& McFarlane, C. (2011). Assemblage and geography. Area, 43, 124-127.

Biehler, D. D., \& Simon, G. L. (2010). The great indoors: Research frontiers on indoor environments as active political-ecological spaces. Progress in Human Geography, 35, 172-192.

Boardman, B. (2010). Fixing fuel poverty: Challenges and solutions. London: Routledge.

Bouzarovski, S., Bradshaw, M., \& Wochnik, A. (2015). Making territory through infrastructure: The governance of natural gas transit in Europe. Geoforum, 64, 217-228.

Bouzarovski, S., Herrero, S. T., Petrova, S., Frankowski, J., Matoušek, R., \& Maltby, T. (2017). Multiple transformations: Theorizing energy vulnerability as a socio-spatial phenomenon. Geografiska Annaler: Series B, Human Geography, 99, 20-41.

Bouzarovski, S., \& Petrova, S. (2015). A global perspective on domestic energy deprivation: Overcoming the energy poverty-fuel poverty binary. Energy Research o Social Science, 10, 31-40.

Bridge, G., Bouzarovski, S., Bradshaw, M., \& Eyre, N. (2013). Geographies of energy transition: Space, place and the low-carbon economy. Energy Policy, 53, 331-340. 
Calvert, K. (2015). From 'energy geography' to 'energy geographies' Perspectives on a fertile academic borderland. Progress in Human Geography, 40, 105-125.

Coutard, O. (2002). The governance of large technical systems. London: Taylor \& Francis.

DeLanda, M. (2006). A new philosophy of society: Assemblage theory and social complexity. London/New York: Continuum.

Energy Vulnerability and Urban Transitions. (2017a). EVALUATE team to host new European energy poverty observatory. http://wp.me/p3gnoe-DL. Retrieved September 1, 2017.

Energy Vulnerability and Urban Transitions. (2017b). The EVALUATE project. http://urban-energy.org/evaluate. Retrieved September 1, 2017.

European Anti-Poverty Network. (2017). Right to energy for all Europeans. http://www.eapn.eu/wp-content/uploads/2017/06/EAPN-2017-letter-toMEPs-Right-to-Energy-Coalition-1225.pdf. Retrieved September 1, 2017.

Harrison, C., \& Popke, J. (2011). 'Because you got to have heat': The networked assemblage of energy poverty in Eastern North Carolina. Annals of the Association of American Geographers, 101, 1-13.

Hilbert, A., \& Werner, M. (2016). Turn up the heat! Contesting energy poverty in Buffalo, NY. Geoforum, 74, 222-232.

Kim, J. S., Lee, I. H., Ahn, Y. H., Lim, S. E., \& Kim, S. D. (2016). An analysis of energy consumption to identify urban energy poverty in Seoul. International Journal of Urban Sciences, 20, 129-140.

Liu, E., Judd, B., \& Santamouris, M. (2017). Challenges in transitioning to low carbon living for lower income households in Australia. Advances in Building Energy Research, 0, 1-16.

Marvin, S. (2012). Conceptual framework: Governance, transitions and cities. Introduction. In S. Guy, S. Marvin, W. Medd, \& T. Moss (Eds.), Shaping urban infrastructures: Intermediaries and the governance of socio-technical networks (pp. 15-16). London: Routledge.

Maxim, A., Mihai, C., Apostoaie, C.-M., \& Maxim, A. (2017). Energy poverty in Southern and Eastern Europe: Peculiar regional issues. European Journal of Sustainable Development, 6, 247.

Oppenheim, J. (2016). The United States regulatory compact and energy poverty. Energy Research o Social Science, 18, 96-108.

Pasqualetti, M. J., \& Brown, M. A. (2014). Ancient discipline, modern concern: Geographers in the field of energy and society. Energy Research os Social Science, $1,122-133$.

Scarpellini, S., Sanz Hernández, M. A., Llera-Sastresa, E., Aranda, J. A., \& López Rodríguez, M. E. (2017). The mediating role of social workers in the implementation of regional policies targeting energy poverty. Energy Policy, 106, $367-375$.

Schneider Electric. (2017). Schneider electric actively develops its programme to fight energy poverty. http://goo.gl/8KzmnA. Retrieved September 1, 2017. 
Sustainable Energy for All. (2017). Our mission. http://www.se4all.org/our-mission. Retrieved September 1, 2017.

Teller-Elsberg, J., Sovacool, B., Smith, T., \& Laine, E. (2016). Fuel poverty, excess winter deaths, and energy costs in Vermont: Burdensome for whom? Energy Policy, 90, 81-91.

Tirado, S., \& Jiménez Meneses, L. (2016). Energy poverty, crisis and austerity in Spain. People, Place and Policy, 10, 42-56.

Williams, J., Wooliscroft, B., \& Lawson, R. (2015). Contrasting approaches to fuel poverty in New Zealand. Energy Policy, 81, 38-42.

Open Access This chapter is distributed under the terms of the Creative Commons Attribution 4.0 International License (http://creativecommons.org/licenses/ by $/ 4.0 /)$, which permits use, duplication, adaptation, distribution and reproduction in any medium or format, as long as you give appropriate credit to the original author(s) and the source, a link is provided to the Creative Commons license and any changes made are indicated.

The images or other third party material in this chapter are included in the work's Creative Commons license, unless indicated otherwise in the credit line; if such material is not included in the work's Creative Commons license and the respective action is not permitted by statutory regulation, users will need to obtain permission from the license holder to duplicate, adapt or reproduce the material.

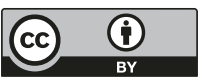

